ISSN: 1948-9900

(C)2013 Science Publications

doi:10.3844/amjnsp.2013.56.59 Published Online 4 (2) 2013 (http://www.thescipub.com/ajn.toc)

\title{
Interaction of $\gamma$ Aminobutyric Acid B Receptors and Electromagnetic Field in the Fear Response
}

\author{
${ }^{1}$ Taherianfard, M., ${ }^{2}$ A. Bahaodini, ${ }^{3}$ M. Fazeli and ${ }^{2}$ S. Karimi Haghighi \\ ${ }^{1}$ Department of Physiology, School of Veterinary Medicine, \\ ${ }^{2}$ Department of Biology, Faculty of Basic Science, \\ ${ }^{3}$ Department of Pharmacology, School of Veterinary Medicine, \\ Shiraz University, P.O. Box: 1731, Shiraz, Iran
}

Received 2012-05-08, Revised 2013-05-25; Accepted 2013-05-30

\begin{abstract}
One of the most neurotransmission system consistently linked with fear response is GABAergic system. GABA through $\mathrm{GABA}_{B}$ receptor can influence fear response. The aim of the present investigation was to

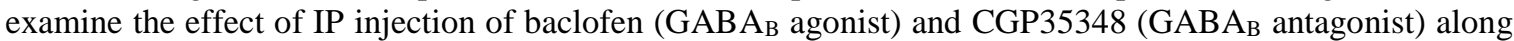
with EMF exposure on frequency of fear response. Fifty adult male rats weighing 180-200 g were used. Animals were divided in ten groups, of which five groups were exposed to ELF-EMF for 30 days at $8 \mathrm{~h}$ day $^{-1}$ in a solenoid, creating an electromagnetic field of $500 \mu \mathrm{T}$ by a $50 \mathrm{~Hz}$ electrical current. Animals were then treated with various doses of baclofen and CGP35348 before being exposed to electrical shock. Each animal were received 100 electrical shocks every session. After shock induction, the fear response was determined by monitoring the reaction of shocked animals to a normal rat which was placed in the electroshock chamber. Data was analyzed by Mann-Whitney test. Significant level was considered to be $\mathrm{p}<0.05$. It was shown that injection of baclofen and CGP35348 did not induce any significant change in fear response in without EMF groups, while both of baclofen and CGP35348 significantly increased frequency of fear response in EMF exposure male rats. Results indicated that GABA $\mathrm{B}$ receptors and EMF exposure possibly involved in the modulation of fear response.
\end{abstract}

Keywords: Fear Response, EMF, Baclofen, CGP35348, Rat

\section{INTRODUCTION}

Along with the rapid increase in the applications of electrical power and electrical facilities, exposures to Extremely Low Frequency Electromagnetic Field (ELF EMF) have significantly been enhanced in term of both intensity and duration (Lacy-Hulbert et al., 1998). It seems that these fields may cause some kind of discomfort and may influence behavior such as increase in passivity and situational anxiety, but has not verified effect on the social and territorial behavior (Balassa et al., 2009).

Santos et al. (2008) showed that GABAergic mechanisms regulate the neural systems that mediate conditioned fear. Researchers showed that inhibition of GABA transmission by GABA-synthesizing enzyme glutamic acid decarboxylase inhibitor (semicarbazide) increased fear conditioned response in the anterior hypothalamic nucleus (Santosand and Brandao, 2011). Specifically, in a conditioned fear paradigm mice deficient in the $\operatorname{GABA}_{\mathrm{B}(1 \mathrm{a}) \text { showed }}$ generalized freezing to both paired and unpaired tones (Shaban et al., 2006).

GABAergic antagonists (bicuculline methiodide and 2-oH-saclofen) block the inhibitory effects of serotonin in the lateral amygdala: a mechanism for modulation of sensory inputs related to fear condition (Stutzmann and

Corresponding Author: Taherianfard, M., Department of Physiology, School of Veterinary Medicine, Shiraz University, P.O. Box: 1731, Shiraz, Iran Tel: 0098-711-2286950 Fax: 0098-711-2286940 
LeDoux, 1999). Baclofen (10 $\mathrm{mg} \mathrm{kg}^{-1}$, IV) inhibited the evoked potential in the lateral amygdala with an effect that was most marked on the positive-going component. Baclofen also significantly reduce paired-pulse inhibition of the negative-going component at short inter pulse intervals (<200 ms) (Sokol et al., 2005). Blockade of $\mathrm{GABA}_{B}$ receptors in the lateral amygdala nucleus by phaclofen generally enhance the electrically elicited medial geniculate nucleus activity. Thus, the electrically induced inputs to the lateral amygdala from the medial geniculate nucleus or auditory association cortex may be under prolonged suppression mediated by $\mathrm{GABA}_{\mathrm{B}}$ receptors in the lateral amygdala. Also, the mediations of auditory fear potentiation of startle are associated with $\mathrm{GABA}_{\mathrm{B}}$ transmissions in the lateral amygdale (Shuchang et al., 2005). Linkage studies directed to a potential involvement of the $\mathrm{GABA}_{\mathrm{B}(1)}$ gene in conditions of panic disorders (Sand et al., 2000).

Activation of both $\mathrm{GABA}_{\mathrm{A}}$ and $\mathrm{GABA}_{\mathrm{B}}$ receptors in the nucleus accumbens shell (AcbSh) decrease the level of fear/anxiety and increase food intake in free-feeding animals, without a positive correlation between both behaviors (Lopes et al., 2007).

So, the aim of the present study was to examine the interaction of $\mathrm{GABA}_{\mathrm{B}}$ receptor agonist (baclofen) and antagonist (CGP35348) along with EMF on the frequency of fear response.

\section{MATERIALS AND METHODS}

\subsection{Animals}

All the procedures involving animal subjects were reviewed and approved by the Institutional Research Ethics Committee of the School of Veterinary Medicine of Shiraz University.

Fifty adult male Sprague-Dawley rats (180-200 gr) were used. The rats were acclimatized for 1 week before being used for the experiment. After preincubation at the same conditions, animals were randomly divided into 10 groups $(n=5)$ : Sham 1 (received normal saline at the same volume of drugs); Sham 2 (exposed to EMF and received normal saline); Experimental 1 (received baclofen at $1.7 \mathrm{mg} \mathrm{kg}^{-1}$ ); Experimental 2 (received baclofen at $3 \mathrm{mg} \mathrm{kg}^{-1}$ ); Experimental 3 (exposed to EMF and received baclofen at $1.7 \mathrm{mg} \mathrm{kg}^{-1}$ ); Experimental 4 (exposed to EMF and received baclofen at $3 \mathrm{mg} \mathrm{kg}^{-1}$ ); Experimental 5 (received CGP35348 at $100 \mathrm{mg} \mathrm{kg}^{-1}$ ); Experimental 6 (received CGP35348 at $200 \mathrm{mg} \mathrm{kg}^{-1}$ ); Experimental 7 (exposed to EMF and received CGP35348 at $100 \mathrm{mg} \mathrm{kg}^{-1}$ ) and Experimental 8 (exposed to EMF and received CGP35348 at $200 \mathrm{mg} \mathrm{kg}^{-1}$ ).

\subsection{Electromagnetic Field Exposure System}

Five groups of animals were exposed to ELF-EMF for 30 days at $8 \mathrm{~h} \mathrm{day}^{-1}$ in a solenoid. The solenoid, a $50 \mathrm{~Hz}$ electrical current, created an electromagnetic field of $500 \mu \mathrm{T}$. Humidity, temperature $\left(23-24^{\circ} \mathrm{C}\right)$ and photoperiod (12h dark: 12h light) reflected natural conditions and were similar in all groups.

\subsection{Drugs}

Baclofen and CGP35348 (prepared from Ciba Gigie as a gift) were diluted in isotonic saline $(0.9 \%)$ and injected intraperitoneally (IP).

\subsection{Behavioral Testing}

Fear response was induced by application of 0.2 $\mathrm{mA}$ electrical current stimulation applied every $3 \mathrm{sec}$ for 5 min, i.e., each animal was received 100 electrical shocks every session. After shock induction, the fear response was determined by monitoring the reaction of shocked animals to a normal rat which was placed in the electroshock chamber. The number of freezing behavior as the sign of fear response was appropriately recorded for $20 \mathrm{~min}$.

\subsection{Statistical analysis}

Data were analyzed using SPSS (version 18). Non parametric test Mann-Whitney to assess the effects of baclofen and CGP35348 on groups of rats subjected to fear response was carried out. Data were presented as Mean \pm SEM. The significant value were considered $\mathrm{p}<0.05$.

\section{RESULTS}

Baclofen at both doses of 1.7 and $3 \mathrm{mg} \mathrm{kg}^{-1}$ showed no significant difference with sham 1 in the frequency of fear response (Table 1). Baclofen at both doses in animals exposed to EMF, significantly $(\mathrm{p}<0.05)$ increased frequency of fear response in comparison to that of sham 2 (Table 1).

CGP35348 at both doses of 100 and $200 \mathrm{mg} \mathrm{kg}^{-1}$ in comparison with sham 1 showed no significant difference in frequency of fear response (Table 2). CGP35348 at both doses in animal exposed to EMF significantly $(\mathrm{p}<0.05)$ increased the frequency of fear response in comparison to that of sham 2 (Table 2). Results showed that the frequency of fear response in sham 2 in comparison to that of sham 1 was significantly $(\mathrm{p}<0.05)$ decreased. 
Taherianfard, M. et al. / American Journal of Neuroscience 4 (2): 56-59, 2013

Table 1. Interaction of EMF and baclofen on frequency of fear response

\begin{tabular}{llll}
\hline Experiment type & Groups & & Frequency of fear response \\
\hline Without exposure to EMF & Sham 1 & $0.96 \pm 0.14^{\mathrm{a}}$ & $0.89 \pm 0.24^{\mathrm{a}}$ \\
& Experimental 1 & Baclofen 1.7 mg kg-1 & $1.02 \pm 0.26^{\mathrm{a}}$ \\
& Experimental 2 & Baclofen 3 mg kg-1 & $0.66 \pm 0.23^{\mathrm{b}}$ \\
With exposure to EMF & Sham 2 & & $1.27 \pm 0.19^{\mathrm{a}}$ \\
& Experimental 3 & Baclofen 1.7 mg kg-1 & $1.19 \pm 0.04^{\mathrm{a}}$ \\
\hline
\end{tabular}

Dissimilar characters showed significant level at $\mathrm{p}<0.05$

Table 2. Interaction of EMF and CGP35348 on frequency of fear response

\begin{tabular}{llll}
\hline Experiment type & Groups & & Frequency of fear response \\
\hline Without exposure to EMF & Sham 1 & $0.96 \pm 0.14^{\mathrm{a}}$ & $0.97 \pm 0.09^{\mathrm{a}}$ \\
& Experimental 5 & CGP35348 100 mg kg-1 & $1.07 \pm 0.15^{\mathrm{a}}$ \\
& Experimental 6 & CGP35348 200 mg kg-1 & $0.66 \pm 0.23^{\mathrm{b}}$ \\
With exposure to EMF & Sham 2 & & $1.03 \pm 0.15^{\mathrm{a}}$ \\
& Experimental 7 & CGP35348 100 mg kg-1 & $0.95 \pm 0.13^{\mathrm{a}}$ \\
\hline
\end{tabular}

Dissimilar characters showed significant level at $\mathrm{p}<0.05$

\section{DISCUSSION}

In the present study, baclofen had no effect on the frequency of fear response in rats without exposure to EMF. It has been shown that baclofen, $30 \mathrm{mg} \mathrm{day}^{-1}$ for 4 weeks, was significantly more effective than placebo in reducing the number of panic attacks and scores on the Hamilton anxiety scale, Zung scale and Katz-R nervousness subscale (Todd and Baker, 1995). Activation of $\mathrm{GABA}_{\mathrm{B}}$ receptor in the nucleus accumbens shell decreased the level of fear/anxiety, without a positive correlation between these behaviors (Lopes et al., 2007). Lopes et al. (2012) reported that the activation of both $\mathrm{GABA}_{\mathrm{A}}$ and $\mathrm{GABA}_{\mathrm{B}}$ receptors within the AcbSh can cause fear/anxiety behavior in $24 \mathrm{~h}$ food-deprived rats as demonstrated by this fact that the injections of both doses of the $\mathrm{GABA}_{\mathrm{A}}$ receptor agonist (muscimul) and $\mathrm{GABA}_{\mathrm{B}}$ receptor agonist (baclofen) decreased the total number of risk assessment exhibition in $24 \mathrm{~h}$ fooddeprived rats (Lopes et al., 2012). In the present study, CGP35348 had no effect on the frequency of fear response in rats without exposure to EMF. Mombereau et al. (2004) reported that the freezing behavior increases in $\mathrm{GABA}_{\mathrm{B} 1}$ receptor deficit mice and

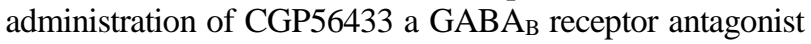
decreases the freezing behavior (Mombereau et al., 2004). The varied results of the present study from those of other studies may be related to the procedure of study. Saclofen, as $\mathrm{GABA}_{\mathrm{B}}$ antagonist, injection in nucleus accumbens shell did not affect the fear/anxiety behaviors (Lopes et al., 2012). 2-OH saclofen blocked the inhibitory effects of serotonin in the lateral amygdala: as a mechanism for modulation of sensory inputs related to fear conditioning (Stutzmann and LeDoux, 1999). In the present study EMF led to diminished frequency of fear response. McKay et al. (2000) reported that magnetic fields display evidence of forgetting, as inferred by their marked attenuation of freezing behavior, during contextual extinction $24 \mathrm{~h}$ later (McKay et al., 2000). On the other hand in the present study EMF and administration of $\mathrm{GABA}_{\mathrm{B}}$ agonist and antagonist increased frequency of fear response. In the literature there was not any study related to interaction of EMF and GABAergic system on fear response; so it seems that clarification of possible mechanisms behind the observed effect needs further studies. The reson that $\mathrm{GABA}_{\mathrm{B}}$ agonist and antagonist had similar effects may be as follow: $\mathrm{GABA}_{\mathrm{B}}$ receptor mainly is presynaptic receptor or auto receptor, but in some synapses it is postsynaptic receptor or both presynaptic and postsynaptic (Kaneda and Kita, 2005; Moldavan et al., 2006). (1) In the present study agonist and antagonist of $\mathrm{GABA}_{\mathrm{B}}$ receptor may act through different receptors, meaning that one of them may act through presynaptic receptor while another one act through postsynaptic receptors. (2) In the present study the lack of the effect of $\mathrm{GABA}_{\mathrm{B}}$ receptor agonist and antagonist may be due to their very small doses on freezing behavior.

\section{CONCLUSION}

In the present study agonist and antagonist of $\mathrm{GABA}_{\mathrm{B}}$ receptor after exposure to $\mathrm{EMF}$ and without exposure to EMF, both similarly increased frequency of fear response. 


\section{ACKNOWLEDGEMENT}

This research was financially supported by Shiraz University.

\subsection{Conflict of interest}

All the authors can confirm that there is no financial or other relationship that would cause a conflict of interest.

\section{REFERENCES}

Balassa, T., R. Szemerszky and G. Bardos, 2009. Effect of short-term $50 \mathrm{~Hz}$ electromagnetic field exposure on the behavior of rats. Acta Physiol. Hung., 96: 437-448. DOI: 10.1556/APhysiol.96.2009.4.4

Kaneda, K. and H. Kita, 2005. Synaptically released GABA activates both pre- and postsynaptic GABA(B) receptors in the rat globus pallidus. J. Neurophysiol., $\quad 94$ : 1104-1114. $\quad$ DOI: 10.1152/jn.00255.2005

Lacy-Hulbert, A., J.C. Metcalfe and R. Hesketh, 1998. Biological responses to electromagnetic fields. FASEB J., 12: 395-420. PMID: 9535213

Lopes, A.P., L. Ganzer, A.C. Borges, L. Kochenborger and A.C. Januário et al., 2012. Effects of GABA ligands injected into the nucleus accumbens shell on fear/anxiety-like and feeding behaviours in fooddeprived rats. Pharmacol. Biochem. Behav., 101: 41-48. DOI: 10.1016/j.pbb.2011.11.013

Lopes, A.P.F., I.C.D. Cunha, S.M. Steffens, A. Ferraz and J.C. Vargas, 2007. $\mathrm{GABA}_{\mathrm{A}}$ and $\mathrm{GABA}_{\mathrm{B}}$ agonist microinjections into medial accumbens shell increase feeding and induce anxiolysis in an animal model of anxiety. Behav. Brain Res., 184: 142-149. DOI: 10.1016/j.bbr.2007.07

McKay, B.E., M.A. Persinger and S.A. Koren, 2000. Exposure to a theta-burst patterned magnetic field impairs memory acquisition and consolidation for contextual but not discrete conditioned fear in rats. Neurosci. Lett., 292: 99-102. PMID: 10998558

Moldavan, M.G., R.P. Irwin and C.N. Allen, 2006. Presynaptic GABA(B) receptors regulate retinohypothalamic tract synaptic transmission by inhibiting voltage-gated $\mathrm{Ca} 2+$ channels. J. Neurophysiol., $\quad 95$ : 3727-3741. DOI: 10.1152/jn.00909.2005

Mombereau, C., K. Kaupmann, W. Froestl, G. Sansig and H.V.D. Putten et al., 2004 Genetic and pharmacological evidence of a role for GABA(B) receptors in the modulation of anxiety- and antidepressant-like behavior. Neuropsychopharmacology, 29: 1050-1062. DOI: 10.1038/sj.npp.1300413
Sand, P.G., C. Godau, P. Riederer, C. Peters and P. Franke et al., 2000. Exonic variants of the GABA(B) receptor gene and panic disorder. Psychiatr Genet., 10: 191-194. PMID: 11324945

Santos, J.M., C.E. Macedo and M.L. Brandao, 2008 Gabaergic mechanisms of hypothalamic nuclei in the expression of conditioned fear. Neurobiol. Learn. Mem., 90: 560-568. DOI: 10.1016/j.nlm.2008.06.007

Santosand, J.M.D. and M.L. Brandao, 2011. Gabaergic mechanisms of anterior and ventromedial hypothalamic nuclei in the expression of freezing in response to a light conditioned stimulus. Psychol. Neurosci., $\quad 4$ : 211-217. DOI: 10.3922/j.psns.2011.2.006

Shaban, H., Y. Humeau, C. Herry, G. Cassasus and R. Shigemoto et al., 2006. Generalization of amygdala LTP and conditioned fear in the absence of presynaptic inhibition. Nat. Neurosci., 9: 1028-1035. DOI: $10.1038 / \mathrm{nn} 1732$

Shuchang, H., H. Juan, W. Xihong and L. Liang, 2005. Glutamate and $\mathrm{GABA}(\mathrm{B})$ transmissions in lateral amygdala are involved in startle-like Electromyographic (EMG) potentiation caused by activation of auditory thalamus. Neurosci., Lett., 374: 113-118. DOI: 10.1016/j.neulet.2004.10.035

Sokol, D.M., A.S. Giarola and C.H. Large, 2005. Effects of $\mathrm{GABA}_{\mathrm{B}}, 5-\mathrm{HT}_{1 \mathrm{~A}}$ and $5-\mathrm{HT}_{2}$ receptor stimulation on activation and inhibition of the rat lateral amygdala following medial geniculate nucleus stimulation in vivo. Brain Res., 1031: 141-150. DOI: 10.1016/j.brainres.2004.10.035

Stutzmann, G.E. and J.E. LeDoux, 1999. GABAergic antagonists block the inhibitory effects of serotonin in the lateral amygdala: A mechanism for modulation of sensory inputs related to fear conditioning. J. Neurosci., 19: RC8-RC8. PMID: 10341269

Todd, K.G. and G.B. Baker, 1995. GABA-elevating effects of the antidepressant/antipanic drug phenelzine in brain: Effects of pretreatment with tranylcypromine, (-)-deprenyl and clorgyline. J. Affective Disorder, 35: 125-129. DOI: 10.1016/0165-0327(95)00056-9 